\title{
Gravity Models of Internal Migration - the Czech Case Study
}

\section{Monika Jandová - Tomáš Paleta ${ }^{1}$}

\begin{abstract}
In this paper, the models of internal migration flows between regions (NUTS 3) in the Czech Republic in time series from 1991 to 2012 are tested. The paper aims to find out how size, distance and economic variables explain migration flows between Czech regions. Several versions of an extended gravity model were used for testing, where economic factors which are frequently mentioned in literature on migration were used as regressors (i.e. average wage, registered unemployment rate, job vacancies and job vacancies per applicant). Internal migration flow is the dependent variable. In comparison to the pure gravity model, the extending of models with the economic variables improves the results of the models only slightly. The results show that the highest explanatory value of migration is given by models with rates of the variables tested.
\end{abstract}

Key words: Gravity model, Internal migration, the Czech Republic, Economic incentives

JEL Classification: J6, J61

\section{Introduction}

Migration is an important determinant of economic growth and enhances labour force utilisation efficiency, both on the international and national level. Results from the national analysis could contribute to verification of migration theories, to identification of potential differences between international and national determinants of migration and can become the groundwork for regional economic policy.

Gravity models are simple but useful tools used in many fields - from geography to international trade. Besides that, gravity models and their variations are among the methods most frequently used for determining incentives to move in studies focusing on migration, both international and internal. ${ }^{2}$

The work of Lewer and Van den Berg (2007) constitutes the fundamental inspiration for our gravity model of migration. The authors found out that in conformity with international trade, migration is driven by attractiveness of individual regions, which is in the

\footnotetext{
${ }^{1}$ Both authors are assistant researchers at the Department of Economics, Faculty of Economics and Administration, Masaryk University. Contact address: Lipová 41a, 60200 Brno. E-mail: jandova@econ.muni.cz and paleta@mail.muni.cz.

${ }^{2}$ When we use the term internal migration, it means inter-regional migration.
} 
case of migration flows measured by the wage difference. Besides, they assumed that number of inhabitants was crucial, too, which was justified by two reasons: i) the more people in a source region, the more people are likely to migrate; and ii) the larger the population in a target region, the larger the labour market for immigrants. Finally, their last inspiration with trade is associated with distance (for more details see Lewer and Van den Berg, 2007).

Many modifications of gravity models can be found in literature. Crozet (2004), for instance, proved that migration flow between two regions increased first with wage difference and a probability to find a new job in a target region, second with the size of a target region, and decreased with the distance between these regions.

In our analysis only migration itself is covered, which means movement of inhabitants from one region to another that is related to changing a permanent address. Migration without official changing of a permanent address or commuting is not involved even if it seems to be a quite important part of flow of inhabitants (especially in case of labour force). ${ }^{3}$

We follow our previous work (Jandová and Paleta, 2011; or Paleta and Jandová, 2013) in our models. Our previous models proved significance of both gravity and economic determinants of migration but since there was still some space for testing new determinants, their results were not sufficient enough. Now, the aim is to find out if the extended gravity model of internal migration with some new variables is capable of explaining migration flows between Czech regions (NUTS 3) better. Besides, we find out what kind of variables (which means whether absolute value, difference or ratio) shows the most statistically important results. The results of our model can answer the question of what is the most important incentive for a migrant, whether she/he moves on the basis of absolute values of the variables, their difference, or their ratio. Moreover, results can be used as a guideline or a methodological tool pro further research in internal migration.

\section{The Starting Point for a Gravity Model}

The original version of the Newton's law of gravitation is that there is an attractive force between two physical objects that is indirectly proportional to the square of the distance between them, and directly proportional to their mass. In non-physical applications, the distance can be measured in kilometres, time or price, and the mass is usually replaced by a number of inhabitants in a region.

In one of our previous papers (see Jandová and Paleta, 2011), we tested solely the gravity variables based on the Newton's law of gravity:

$$
\log \left(M F_{i j}\right)=\alpha_{0}+\alpha_{1}\left(P O P_{j}\right)+\alpha_{2}\left(P O P_{i}\right)+\alpha_{3}\left(D I S T_{i j}\right)
$$

in which $\log \left(M F_{i j}\right)$ is a logarithm of migration flows from a source to a target region; $P O P_{j}$ is a number of inhabitants in a target region; $P O P_{i}$ is a number of inhabitants in a

\footnotetext{
${ }^{3}$ Its extent could be only estimated, especially on basis of survey questionnaire.
} 
source region; $D I S T_{i j}$ is a distance between capitals of regions; $\alpha_{0}$ is a constant; and $\alpha_{1 \ldots 3}$ are coefficients.

The results for the period of 1991-2009 were quite satisfactory; both "gravity" variables proved to be important determinants of internal migration in the Czech Republic. Specifically, the result was that each kilometre of distance decreased migration flows by $0.635 \%$. The influence of region sizes was proved as well, regardless of the fact if it was a source or a target region. It was shown that population growth of 100 thousand inhabitants increased migration flows by $14 \%$.

Our model was inspired by models dealing with international migration. Although some of the determinants of international migration (e.g. language or culture) are absent in the decision-making of an "internal migrant", we suppose that there is no difference in the fundamental incentives to move. We built our model on the gravity migration model of Lewer and Van den Berg (2007) mentioned above. Their equation was:

$$
\begin{gathered}
\operatorname{Imm}_{i j}=a_{0}+a_{1}\left(\text { pop }_{i} \cdot \text { pop }_{j}\right)+a_{2}\left(\text { rely }_{i j}\right)+a_{3}\left(\text { dist }_{i j}\right)+a_{4}\left(\text { stock }_{i j}\right) \\
+a_{5} L A N G_{i j}+a_{6} \operatorname{CONT}_{i j}+a_{7} \operatorname{LINK}_{i j}+u_{i j}
\end{gathered}
$$

in which $\operatorname{Imm}_{i j}$ is a logarithm of immigration to a target region; $\operatorname{pop}_{i} \cdot p o p_{j}$ is a multiple of population sizes; rely $y_{i j}$ is a ratio of per capita incomes between a target and a source country; dist $_{i j}$ is a distance between regions; $s t o c k_{i j}$ is a number of source region natives already living in a target region; and finally $L A N G, C O N T$ and LINK are dummy variables for pairs of regions that share a common language, a contiguous border and colonial links; $a_{0}$ is a constant; and $a_{1 \ldots 7}$ are coefficients.

In the view of the fact that their model was devised for international migration, we had to do some important modifications to better fit internal conditions (see Jandová and Paleta, 2011). First, we removed irrelevant variables such as common language, colonial relations, contiguous borders and a number of natives from a source region. Moreover, we replaced Lewer and Van den Berg's equivalent of mass - GDP per capita - with an average wage because it seemed to be a more important determinant of internal migration than GDP itself. On the other hand, we were aware of the fact that GDP per capita and an average wage for a particular region was highly correlated - at least in the Czech Republic. Our equation in Jandová and Paleta (2011) was formulated as follows:

$$
\begin{aligned}
\log \left(M F_{i j}\right)=\beta_{0}+ & \beta_{1}\left(P O P_{j}\right)+\beta_{2}\left(P O P_{i}\right)+\beta_{3}\left(W_{j} / W_{i}\right)+\beta_{4}\left(D I S T_{i j}\right) \\
& +\beta_{5}\left(U_{i}\right)+\beta_{6}\left(U_{j}\right)+\beta_{7}\left(F W P_{j}-F W P_{i}\right),
\end{aligned}
$$

in which $\log \left(M F_{i j}\right)$ is a logarithm of migration flows from a source to a target region; $P O P_{j}$ is a number of inhabitants in a target region; $P O P_{i}$ is a number of inhabitants in a source region; $W_{j} / W_{i}$ is a ratio of wages between a target and a source region; $D I S T_{i j}$ is a distance between capitals of regions; $U_{i}$ is a rate of unemployment in a source region; $U_{j}$ is a rate of unemployment in a target region; $F W P_{j}-F W P_{i}$ is a difference between job vacancies in a target and a source region; $\beta_{0}$ is a constant; and $\beta_{1 . . .7}$ are coefficients.

This economic model, which was tested on the data set for years 1991-2009, seemed to be more exact than the gravity one. On the other hand, economic variables did not prove to be as significant as we had supposed. The growth of the unemployment rate by 1 
percentage point in a source region increased migration flow from that source region by $2.4 \%$, and contrarily, decrease of unemployment in the target region intensified the inflow of migrants by $1.9 \%$. In the case of wage ratio between regions, the model showed that the increase of wage ratio of 1 percentage point increased migration by $27 \%$, however, the reliability level was lower than in the case of previous variables.

Finally, we built our model on Paleta and Jandová (2013), where modifications were as follows:

$$
\begin{aligned}
\log \left(M F_{i j}\right)=\beta_{0}+ & \beta_{1}\left(\text { Wdiff }_{j i}\right)+\beta_{2}\left(\text { UNdiff }_{j i}\right)+\beta_{3}\left(\text { JVdiff }_{j i}\right) \\
& +\beta_{4}(\text { gravity })
\end{aligned}
$$

In the equation, $\log \left(M F_{i j}\right)$ is a logarithm of migration flows from a source to a target region; $W$ diff $f_{j i}$ is the average wage in a target region minus an average wage in a source region; $U N$ diff $f_{j i}$ is a registered unemployment rate in a target region minus a registered unemployment rate in a source region; and $J V d i f f_{j i}$ is a number of job vacancies in a target region minus a number of job vacancies in a source region; gravity is our combined variable of size and distance; $\beta_{0}$ is a constant; and $\beta_{1-4}$ are coefficients. Since distance did not vary within the time and therefore could not be used in the panel data model directly due to its full collinearity, we constructed a new variable based on the Newton gravity law. In our case, gravity equals to a population size of a source region (in thousands) which is multiplied by a population size in a target region and divided by square of distance (in kilometres) of the regions' capitals. The coefficient could be interpreted as an inter-regional "gravity constant", which must not be mistaken for "gravity force". It is impossible in this case of constructed regressor to distinguish whether the influence is bigger for distance or for size; only joint influence can be tested. When interpreting the "gravity constant", it is necessary to bear in mind that the independent variable is in the log form.

In compliance with our model in Jandová and Paleta (2011), we took into account a difference in job vacancies between regions. Since we assumed that the difference is what people motivate to migrate, other variables were modified into a form of difference.

The results of this model proved that all three economic variables included (i.e. wage difference, unemployment difference, and difference in job vacancies) were statistically significant. The question is which other economic determinants of migration are suitable as a supplement to our model. The problem of long time unemployment suggests that the probability of finding new job could be more important than we had assumed.

\section{Incentives to Move - Theory and Evidence from Other Models}

According to the oldest neoclassical macroeconomic theories migration is caused by geographic differences in the supply of labour and demand for labour (Masey et al., 1993). 
Generally speaking, migration is determined by push and pulls factors. In accordance with neoclassical microeconomic theory, Price (1951) stated that people move in order to improve their standards of living, both economic and social. ${ }^{4}$ From this point of view, people who have decided to migrate choose a region associated with the maximum net benefit from migration (Greenwood, 1974).

Wage difference (see e.g. Massey et al., 1993) is one of the most important pull factors used in macroeconomic models of migration. This determinant was simultaneously confirmed by both models we dealt with previously. In the case of the Czech Republic it is not surprising as e.g. Fidrmuc (2004) and Lux et al. (2006) proved that internal migration is strongly correlated to average wage. This is why it is unreasonable to reject this variable from our model.

Push factors are commonly represented by a high rate of unemployment in a source region and/or a job loss of a migrant. Migrants move from regions with high unemployment to regions with employment prospects (Fidrmuc, 2004). Moreover, according to Boeri and Scarpetta (1996), regional unemployment differentials were larger in the Czech Republic (and other transition countries) than in the EU-12. Both of the determinants stated above, i.e. a wage level and an unemployment rate, represent possible important migration incentives but they are not the only ones (see Peker, 2004). Wage difference as an attractive force can be overweighed by a low probability of finding a job. Todaro (1968 in World Bank, 2007) explained that a 70 percent wage difference has a small impact on migration if the probability of finding a job is low (he stated one to fifty). In the case of the Czech Republic, Srb (1999) found out that migration is correlated, besides other things, to differences in job opportunities. Paleta and Jandová (2013) represented the probability of finding a new job by a difference in job vacancies. Unfortunately, this variable did not reflect number of applicants, which is why modification of the variable seems desirable.

Distance of regions is another factor determining a willingness to migrate. According to Price (1949), for instance, we can expect that the number of migrants decreases with increasing distance, but only in the case of uniform opportunities. On the contrary, Drobne and Rajar and Lisec (2013) discovered that better transport and working conditions (i.e. flexible working time or work from home) have a significant positive effect on our decisions related to commuting instead of migrating. From this point of view, distance does not seem to play as important role as before but the final impact on migration is the same.

In total, many authors of empirical studies focused primarily on wage difference and a rate of unemployment, and a distance as factors determining migration costs (see Borjas, 2010). Besides, we have to admit that there is some evidence confirming the significance of labour force characteristics (i.e. skills (Dohmen, 2011; or Srb, 1999), risk aversion (WB, 2007), ownership of houses (Oswald, 1996), age (Vavrejnová, 2004), sex or

\footnotetext{
${ }^{4}$ The neoclassical microeconomic theory of migration presumes that rational individuals decide to migrate because a cost-benefit calculation (Masey et al., 1993).
} 
family status (Dennett and Stillwell, 2008)). These socio-demographic variables were confirmed as incentives for internal migration in the Czech Republic as well (see Vajdová, 2002; Fidrmuc and Huber, 2007; or Drbohlav, 1990). A survey on migrants' incentives described in Vajdová (2002) demonstrated a low significance of economic factors; it revealed that an effort to find a new job accounted for only about 13-17\%. Unfortunately, socio-demographic data are currently inaccessible from the official resources, which is why we cannot include them into our model.

\section{Method}

As was already mentioned, this paper is a follows-up to our previous work published in 2011 and 2013 (see Jandová and Paleta, 2011; or Paleta and Jandová, 2013). We extend the data set with new time series (for the year 2012). Unless stated otherwise, Czech Statistical Office (CZSO) is the source of all the data used. Migration data have been collected from various issues of statistical yearbooks, regional division CZSO websites, archives or specific yearbooks focused on migration. ${ }^{5}$

Unlike the previous papers, we have tested several different models with different variables this time. Our primary question is whether people take into account values, differences or rates of involved variables. If one of our models gives substantially better results, we could make a conclusion about what kind of data people take into consideration. We have tested all models on panel data for the regions of the Czech Republic. The length of the time series differs according to availability of the data (see Table 1).

On the basis of theoretical literature and previous research we formulated the following hypotheses considering the regressors:

1) Wage difference is a factor forcing the migration - the higher the difference (target minus source), the stronger motivation to migrate. We expect the coefficient in model results to be positive (both in case of difference and ratio);

2) Unemployment rate difference is a factor preventing migration - the higher the difference (target minus source), the stronger motivation not to migrate. We expect the coefficient in the model results to be negative (both in case of difference and ratio);

3) And the same as for wage difference, difference in a number of job vacancies is a factor forcing the migration. We expect the coefficient in the model results to be positive.

At the very beginning, we test the "pure" gravity model, looking for the influence of size (population) and distance only. We use the logarithm of migration flow between the regions as the dependent variable in all models presented. The logarithm helps us avoid possible heteroscedasticity problem; in addition to it, it is also better for model interpretation.

The pure gravity model equation is as follows:

\footnotetext{
${ }^{5}$ The collected data set can be provided on request.
} 


$$
\log \left(M F_{i j}\right)=\alpha_{0}+\alpha_{1} \text { (gravity) }
$$

Such a starting point allows us to compare the influence of additional variables. In turn we built up five models with different regressors.

We use the same approach as in Paleta and Jandová (2013) in the first extended model (6); see above for description of variables. We use inter-regional differences because we suppose that the difference is what the migrants take into account. The extended gravity model equation can be formulated as follows:

$$
\begin{aligned}
\log \left(M F_{i j}\right)=\beta_{0}+ & \beta_{1}\left(\text { Wdiff }_{j i}\right)+\beta_{2}\left(\text { UNdiff }_{j i}\right)+\beta_{3}\left(\text { JVdiff }_{j i}\right) \\
& +\beta_{4}(\text { gravity })
\end{aligned}
$$

We used the same variables as in (6) in our next model (7) but in a different form. Now we did not deal with differences, but rates instead.

The extended gravity model with rates has the following equation:

$$
\begin{aligned}
\log \left(M F_{i j}\right)=\chi_{0} & +\chi_{1}\left(\text { Wrate }_{j i}\right)+\chi_{2}\left(\text { UNrate }_{j i}\right)+\chi_{3}\left(\text { JVrate }_{j i}\right) \\
& +\chi_{4}(\text { gravity } .
\end{aligned}
$$

The additional variables are as follows: Wrate $_{j i}$ is a rate of wages in a target region and a source region; UNrate $_{j i}$ is a registered rate of unemployment in a target region divided by a registered rate of unemployment in a source region; JVrate ${ }_{j i}$ is a number of reported job vacancies in a target region divided by a number of reported job vacancies in a source region; and gravity is the same combined variable of population size and distance as in the previous model (6).

Our third extended gravity model (8) tested the values of variables for both target and source region. We involved the gravity variable, too. The equation of extended gravity model with values is as follows:

$$
\begin{aligned}
\log \left(M F_{i j}\right)=\delta_{0}+ & \delta_{1}(\text { gravity })+\delta_{2}\left(\text { Wage }_{j}\right)+\delta_{3}\left(\text { Wage }_{i}\right)+\delta_{4}\left(J V_{j}\right) \\
& +\delta_{5}\left(U N_{i}\right) .
\end{aligned}
$$

Quite a lot of variables proved to be statistically insignificant in this model, which was the reason we omitted them. The following variables were significant: $W a g e_{j}$, i.e. wage in a target region; $W a g e_{i}$, i.e. wage in a source region; $J V_{j}$, i.e. job vacancies in a target region; $U N_{i}$, i.e. rate of registered unemployment in a target region; and gravity.

We add another variable into the last two models: job vacancies per applicant, first (9) in a difference, and second (10) in an absolute value form. This variable can be used as another (and probably better) proxy for probability of finding a new job, than only job vacancies numbers. Since the time series of the data available includes only 11 years, we do not incorporate this variable in our previous models $(6,7,8)$. Instead of that, we build two separate models with this variable $(9,10)$.

$$
\log \left(M F_{i j}\right)=\varepsilon_{0}+\varepsilon_{1}(\text { gravity })+\varepsilon_{2}\left(\text { JVAPdif }_{j i}\right) .
$$


In the model in a form of differences (9), $W \operatorname{diff} f_{j i}$ and $U N \operatorname{diff} f_{j i}$ prove to be insignificant. Only gravity and $J V A P \operatorname{diff} f_{j i}$ are statistically significant, where $J V A P \operatorname{dif} f_{j i}$ is a number of job vacancies per applicant in a target minus a number of job vacancies per applicant in a source region.

The equation for the absolute value form is as follows:

$$
\log \left(M F_{i j}\right)=\varphi_{0}+\varphi_{1}(\text { gravity })+\varphi_{2}\left(U N_{i}\right)+\varphi_{3}\left(J V A P_{j}\right) .
$$

In the last model (10), variables $W_{j}, W_{i}$ and $U N_{j}$ were insignificant, such as was the number of job vacancies per applicant in a source region $\left(J V A P_{i}\right)$. The number of job vacancies per applicant in a target region $\left(J V A P_{j}\right), U N_{i}$ and again gravity were the only significant variables.

In order to estimate the results, panel data model with fixed effect was used. To avoid the problem of autocorrelation and heteroscedasticity we used robust standard errors (HAC) estimation. We also used log form of dependent variable to deal with heteroscedasticity, and also because of more convenient interpretation.

The model for the Czech Republic as a whole includes 182 cross-sectional units (migration flows to and from the same region are omitted), the length of time series varies between 22 (1991-2012) to 11 (2002-2012) because of (un)availability of any older data. The summary of the results of our models is displayed in Table 1.

As we can see, the gravity coefficient is positive in all cases, so we can confirm that gravity matters in the case of internal migration in the Czech Republic. The pure gravity model, based only on gravity, has quite a high coefficient of determination, and the coefficient for gravity is (logically) highest in comparison with other tested models. The high $\mathrm{R}^{2}$ could be explained either by: i) high importance of gravity, or (and) ii) by stability of migration flow in the period under observation, which gives only little significance to our variables. The second explanation mentioned is also confirmed by the results of the other models. Additional variables improve $\mathrm{R}^{2}$ only slightly and the relevance of the variables tested is quite low. In model (6), for example, the CZK 1000 difference in average wage explains only $0.03 \%$ of migration flow; one percentage point difference in unemployment rate influences migration only by $1 \%$; and job vacancies difference of 1000 influences the migration flows only by $0.6 \%$. Such results are almost the same as in our previous work (see Paleta and Jandová, 2013).

At the first glance, explanatory value of the coefficients in model (7) is much higher. For example increase of Wrate (i.e. wage rate) by one increases migration by $130 \%$. But such an increase would require bigger wage differences than those that actually occur in the Czech Republic (an increase of Wrate from 1 to 2 would require doubling of wage level in a target region). However, we can say that rate plays a more important role as the factor of migration than the difference does. The model with values (8) also has high $\mathrm{R}^{2}$, and most of its variables are significant. Its explanatory value, nonetheless, is as low as that of the model (6). 
Table 1 Results of the Gravity and Extended Gravity Models for the Czech Republic

\begin{tabular}{|c|c|c|c|c|c|c|}
\hline Model $\rightarrow$ & & & & & & \\
\hline $\begin{array}{c}\downarrow \text { Independent } \\
\text { variable }\end{array}$ & Gravity (5) & Diff (6) & Rates (7) & $\begin{array}{l}\text { Values } \\
\text { (8) }\end{array}$ & $\begin{array}{l}\text { JVAPdift } \\
\text { (9) }\end{array}$ & JVAPvalues (10) \\
\hline Const & $\begin{array}{c}5.27 \\
(970)^{* \star *}\end{array}$ & $\begin{array}{c}5.27 \\
(1669)^{\star * *}\end{array}$ & $\begin{array}{c}3.92 \\
(15.21)^{\star \star \star}\end{array}$ & $\begin{array}{c}5.12 \\
(208.4)^{\star * *}\end{array}$ & $\begin{array}{c}5.34 \\
(4244)^{\star * *}\end{array}$ & $\begin{array}{c}5.53 \\
(149.3)^{\star \star *}\end{array}$ \\
\hline Wrate $_{j i}$ & - & - & $\begin{array}{c}1.3 \\
(5.08)^{\star \star \star}\end{array}$ & & & \\
\hline Wdiffjil(1000) & - & $\begin{array}{c}0.0003 \\
(2.45)^{* *}\end{array}$ & 1 & - & INS & - \\
\hline UNrate $_{\mathrm{ji}}$ & - & - & $\begin{array}{l}-0.012 \\
(-2.24)^{* *}\end{array}$ & - & - & - \\
\hline UNdiffji & - & $\begin{array}{c}-0.01 \\
(-2.51)\end{array}$ & - & - & INS & - \\
\hline JVrate $_{j i}$ & - & - & $\begin{array}{l}0.054 \\
(7)^{\star \star \star}\end{array}$ & - & - & - \\
\hline$J_{V} \operatorname{diff}_{\mathrm{ji}}$ & - & $\begin{array}{l}0,000006 \\
(2.61)^{* * *}\end{array}$ & - & - & - & - \\
\hline Gravity & $\begin{array}{c}0.00029 \\
(10.09)^{\star * *}\end{array}$ & $\begin{array}{l}0,00019 \\
(6.14)^{\star * \star}\end{array}$ & $\begin{array}{l}0.00023 \\
(5.4)^{* * *}\end{array}$ & $\begin{array}{l}0.00017 \\
(2.7)^{* \star *}\end{array}$ & $\begin{array}{c}0.00015 \\
(16.65)^{* \star *}\end{array}$ & $\begin{array}{l}0.000177 \\
(11.28)^{\star * *}\end{array}$ \\
\hline JVAPdiffji & - & - & - & - & $\begin{array}{c}0.079 \\
(1.95)^{\star}\end{array}$ & - \\
\hline Wt & - & - & - & $\begin{array}{l}0,000038 \\
(4.57)^{\star \star \star}\end{array}$ & - & INS \\
\hline Ws & - & - & - & $\begin{array}{l}-0,00002 \\
(-2.37)^{* *}\end{array}$ & - & INS \\
\hline $\mathrm{JV}_{\mathrm{j}}$ & - & - & - & $\begin{array}{l}0.000015 \\
(12.9)^{\star \star \star}\end{array}$ & - & - \\
\hline$J V_{i}$ & - & - & - & INS & - & - \\
\hline$U N_{j}$ & - & - & - & $\begin{array}{c}-0.02 \\
(-10.7)^{\star \star \star}\end{array}$ & - & INS \\
\hline UNi & - & - & - & INS & - & $\begin{array}{c}-0.024 \\
(-6.44)^{\star \star \star}\end{array}$ \\
\hline$J_{V A P}$ & - & - & - & - & - & $\begin{array}{c}0.17 \\
(4.71)^{\star * \star}\end{array}$ \\
\hline JVAPi & - & - & - & - & - & INS \\
\hline $\mathrm{R}^{2}$ & 0.94 & 0.95 & 0.96 & 0.96 & 0.96 & 0.975 \\
\hline $\begin{array}{l}\text { Observation/ } \\
\text { time series }\end{array}$ & $4004(22)$ & $3620 / 20$ & $2912 / 16$ & $3640 / 20$ & $1991 / 11$ & $2002 / 11$ \\
\hline
\end{tabular}

Note: In the case that some variables proved to be insignificant, they were removed from the model (and market as INS in the table). The sign "- " (without any value) means that a particular variable was not used it the particular model. Presented are results of models where insignificant variable(s) were omitted in the final calculation.

Source: Own calculations (using Gretl software)

The last models (9) and (10) are tested on a shorter time series, so they are not fully comparable with other models. Nevertheless, their results are interesting. Adding a number of job vacancies per applicant as a variable makes most of other variables insignificant, and it also increases the $\mathrm{R}^{2}$ in the case of model (10). This could be interpreted 
in such a way that probability of finding new job is very important factor for migration, and is even more important than potentially higher wage.

We tested several gravity models of internal migration in the Czech Republic in our paper, estimating parameters of our models on the panel data. The aim of the paper was to find out what economic variables are decisive for inter-regional migration flows in the Czech Republic and what form (difference, ratio or absolute value) has the most statistically significant results.

The data set was used with awareness of their limited information capability, when a part of labour force move is not associated with a change of permanent address, and furthermore a part of migrants changing a permanent address is not forced by economic incentives. Up to 22-year-long time series were used (from 1991 to 2012) in order to find out what form of economic variable migrants take into account. The results of the model suggest that migration is best explained by ratios of variables. Differences and values of variables have quite a low explanatory value. It can be interpreted that a migrant seems to be more interested in a question of "how many times" (represented by a ratio) than in "how much" (represented by a difference). This finding can be used as a starting point for an international comparison of internal migration.

Gravity, a combined variable of size and distance, created according to the Newton gravity laws, explains the migration well, too. Results of the model suggest that economic variables improve interpretation capability slightly, and a large part of migration flows seems to be determined by distance of regions, their size or by other than economic factors that were not covered in this model (due to their inaccessibility). ${ }^{6}$

Generally, our results are in conformity with theoretical assumptions and with most of empirical evidence for international migration. But in the case of inter-regional migration in the Czech Republic, the role of economic variables seems to be weak. The results confirm conclusions from Fidrmuc (2004) and Fidrmuc and Huber (2007), i.e. that the economic factors have quite a low impact on internal migration flows in the Czech Republic. Income (wage) and job vacancies per applicant are the most significant economic factors of migration. In the case of shorter time series (model 9 and 10) it seems that the probability of finding a new job is very important factor for migration, and is even bigger than the potentially higher wage (which is in conformity with Todaro 1968 in World Bank 2007).

The unemployment rate has only small impact on the migration flows. This conclusion is in contrast with that of Boeri and Scarppeta (1996) who stated that net migration flows are indeed negatively correlated to unemployment.

Finally, we have to admit that there is an opposite trend, especially in the vicinity of Prague, where inhabitants change the permanent address and move to the Středočeský kraj (Central Bohemian Region) without actually changing their jobs. The quite heavy migration flow from Prague weakens the role of economic factors in the results of our

\footnotetext{
${ }^{6}$ Especially social factors (see e.g. Fidrmuc and Huber, 2007).
} 
models. We can expect a stronger real impact of economic variables than expressed in the results of our model.

\section{References}

BOERI, T., SCARPETTA, S. (1996). Regional Mismatch and the Transition to a Market Economy. Labour Economics 3, pp. 233-254.

BORJAS, G. J. (2010). Labor Economics. Boston: McGraw Hill.

CROZET, M. (2004). Do migrants follow market potentials? An estimation of a new economic geography model. Journal of Economic Geography. 4, pp. 439-458.

Database of the Czech Statistical Office. Available from Internet: www.czso.cz.

DENNETT, A., STILLWELL, J. (2008). Internal migration in Great Britain - a district level analysis using 2001 Census data. WP 01/08, University of Leads.

DOHMEN, T. (2000). Housing, mobility and unemployment. Discussion Paper No. 210.

DRBOHLAV, D. (1990). Migrační motivace, regionální a sídelní preference obyvatelstva. Sociologický časopis. 26(5), pp. 358-374.

DROBNE, R., RAJAR, T., LISEC, A. (2013). Dynamics of Migration and Commuting to the Urban Centres of Slovenia, 2000-2011. Geodetski vestnik. 57/2, pp. 333-353.

FIDRMUC, J. (2004). Migration and regional adjustment to asymmetric shocks in transition economies. Journal of Comparative Economics 32, pp. 230-247.

FIDRMUC, J., HUBER, P. (2007). The willingness to migrate in the CEECs. Evidence from the Czech Republic. WIFO Working Papers 286.GREENWOOD, M. J. (1974). Research on Internal Migration in the United States: A Survey. Journal of Economic Literature. 13(2), pp. 397-433.

JANDOVÁ, M., PALETA, T. (2011). Vnitřní migrace, In: Slaný, A. et al. (eds.), Konkurenceschopnost, růstová výkonnost a stabilita české ekonomiky (pp. 41-56). Brno: Masarykova univerzita.

LEWER, J. J., BERG, H. van den (2007). A Gravity Model of Immigration. Economic Letters, 99, pp. 164-167.

LUX, M. et al. (2006). Analýza opatření bytové politiky směřujících k podpoře flexibility práce v ČR. 1. díl, teoretický úvod. Praha: Sociologický ústav AV ČR.

MASSEY, D. S. et al. (1993). Theories of International Migration: A Review and Appraisal. Population and Development Review. 19(3), pp. 431-466.

OSWALD, A. (1996). A Conjecture on the Explanation for High Unemployment in the Industrialized Nations: Part I. Warwick Economic Research Paper No. 475.

PALETA, T., JANDOVÁ, M. (2013). Incentives to move: a model of inter-regional migration in the Czech Republic, In Machová, Z., Uhrová, N. Economic Policy in the European Union Member Countries (pp. 270-282). Ostrava: VŠB - Technical university Ostrava, 2013. 
PEKER, K. (2004). The causes and results of internal migration from rural areas: case of Eastern Anatolia. Agricultural Economics. 50(10), pp. 471-476.

PRICE, D. O. (1949). Distance and Direction as Vectors of Internal Migration. Social Forces. 1, pp. 48-53.

PRICE, D. O. (1951). Some Socio-Economic Factors in Internal Migration. Social Forces. 4, pp. 409-415.

SRB, V. (1999). Vnitřní stěhování 1991-1997 podle důvodů migrace. Urbanismus a územní rozvoj. 3, pp. 8-14.

VAJDOVÁ, Z. (2002, February 6). Kdo, kam a proč se v minulosti stěhoval? Postoje k bydlení V ČR 2001. Retrieved September 11, 2010, from http://seb.soc.cas.cz/postoje2001/prezentace/seb_vajdova_drahy.pdf

VAVREJNOVÁ, M. (2004). Mobilita pracovní síly před a po vstupu ČR do EU. Acta Oeconomica Pragensia. 12(3), pp. 195-218.

World Bank. (2007, January 8). Overview of Migration Trends in Europe and Central Asia, 1990-2004. Retrieved August 29, 2010, from http://siteresources.worldbank.org/INTECA/Resources/2578961167856389505/Migration_Chapter3.pdf. 